\title{
Sorption and redox processes controlling arsenic fate and transport in a stream impacted by acid mine drainage
}

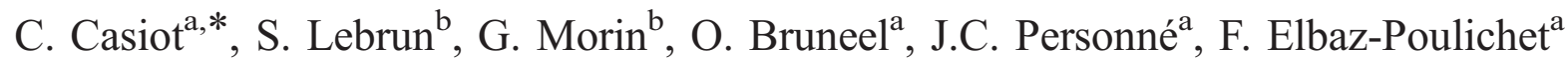 \\ ${ }^{a}$ Laboratoire Hydrosciences Montpellier, UMR 5569 CNRS-IRD-UM1 and 2, Université Montpellier 2, \\ Place E. Bataillon, Case MSE, 34095 Montpellier Cedex 05, France \\ ${ }^{\mathrm{b}}$ Laboratoire de Minéralogie-Cristallographie, UMR CNRS 7590, Universités Paris 6 et 7, et IPGP, \\ 4 Place Jussieu 75252 Paris Cedex 05, France
}

\begin{abstract}
Reigous acid creek originating from the Carnoulès tailings impoundment supplies high concentrations of arsenic under soluble (up to $4 \mathrm{mg} / \mathrm{l}$ ) and particulate (up to $150 \mathrm{mgAs} / \mathrm{g}$ ) phases to the Amous river, situated at the drainage basin of the Rhône river (Southern France). The metalloid is present as As(III) (>95\%) in Reigous creek water while As(V) predominates $(50-80 \%)$ in the solid phase, i.e. schwertmannite. At the confluence between acid $(\mathrm{pH}<5)$ creek and alkaline Amous river, As(III) concentrations decrease ten-fold through dilution and formation of As-rich ferrihydrite ( $\mathrm{As} / \mathrm{Fe}=0.02-0.1)$ containing 10 $30 \% \mathrm{As}(\mathrm{III})$. However, these attenuation processes are not efficient in the summer heatwave of 2003 since As concentrations in Amous river water $(\geq 20 \mu \mathrm{g} / \mathrm{l})$ and $\mathrm{As} / \mathrm{Fe}$ ratios in particulate matter $(\geq 0.07)$ are closed to those of Reigous creek $(\leq 22 \mu \mathrm{g} / \mathrm{l}$ and $\leq 0.02$, respectively) or even higher. Downstream the confluence, processes involved in the transport of aqueous As along Amous river flowpath vary seasonally. Arsenic is transported conservatively in the aqueous phase away from the confluence in the cooler months; thus, dilution by unpolluted tributaries is the only process that decreases As concentrations. However, As(III) is rapidly oxidized and $\mathrm{As}(\mathrm{V})$ remains in solution. In contrast, during the warm season, desorption from As-rich sediment occurs which results in an increase of $\mathrm{As}(\mathrm{V})$ and $\mathrm{As}(\mathrm{III})$ concentrations along Amous river flow until they reach up to $\sim 20 \mu \mathrm{g} / 1$ each. Therefore, Amous river seems not to be totally recovered from mine-related arsenic contamination after $3.5 \mathrm{~km}$ and may affect freshwater resources further downstream.
\end{abstract}

Keywords: Arsenic; Speciation; AMD; Transport processes; Mine-impacted river

\section{Introduction}

* Corresponding author. Tel.: +334671433 56; fax: +3346714 4774.

E-mail address: casiot@msem.univ-montp2.fr (C. Casiot).

The concentrations of arsenic in acid mine drainage (AMD) can reach hundreds of $\mathrm{mg} / \mathrm{l}$, as a result of the oxidation of As-rich sulfides (Williams, 2001). Such 
As concentrations are potentially harmful for the aquatic ecosystem located downstream from mining sites and compromise a significant part of freshwater resources.

In AMD, aqueous arsenic occurs either as As(III) or As(V) (Williams, 2001). Although in rare cases the precipitation of tooeleite, an $\mathrm{As}(\mathrm{III})-\mathrm{Fe}(\mathrm{III})$ mineral, has been observed (Morin et al., 2003), the As(III) form, which is believed to be the most toxic, is rather stable in solution, especially at low $\mathrm{pH}$. On the contrary, $\mathrm{As}(\mathrm{V})$ presents a strong affinity for $\mathrm{Fe}(\mathrm{III})$. In AMD from the former Carnoulès mine (France), the formation of an amorphous $\mathrm{As}(\mathrm{V})-\mathrm{Fe}(\mathrm{III})$-oxyhydroxysulfate precipitate has been reported (Leblanc et al., 1996; Morin et al., 2003). More frequently, As(V) forms scorodite (Roussel et al., 1999) or adsorbs on schwertmannite and ferrihydrite as a function of $\mathrm{pH}$ (Carlson et al., 2002).

When transported downstream during floods, these minerals may dissolve upon water neutralization and release their As. The dissolution of As may be counteracted by the precipitation of $\mathrm{Fe}$ - or Al-oxyhydroxides which efficiently scavenge As(V) (Kimbal et al., 1995). Depending on local site conditions, the As concentration and partitioning between the solid phase and the solution may be further modified along the flowpath by $\mathrm{pH}$ and redox condition changes (Fuller and Davis, 1989).
A principal issue for the assessment of As mobility is the elucidation of the forms in which arsenic is transported or immobilized.

The aim of this study was to deepen the understanding of the processes which control the transport and fate of arsenic in mining environments. Therefore, we studied arsenic speciation and partitioning in the Amous river, which receives acid mine drainage from an abandoned $\mathrm{Pb}-\mathrm{Zn}$ mine in Southern France.

\section{Site description}

The mine of Carnoulès (Fig. 1a) is located in Southern France in the drainage basin of the Rhône river. The mining activity, stopped in 1962, has left about $1.5 \mathrm{Mt}$ of sulfidic wastes containing $0.7 \% \mathrm{~Pb}$, $10 \% \mathrm{Fe}$ and $0.2 \%$ As deposited over a segment of the Reigous Creek (Leblanc et al., 1996). The seepage water, which percolates through the wastes, emerges at the bases of the impoundment and forms the spring of the Reigous creek. The water is acidic ( $\mathrm{pH} 3-4.5)$ and contains up to $250 \mathrm{mg} \cdot 1^{-1}$ of As in the As(III) form (Casiot et al., 2003). The As concentration decreases within the first $30 \mathrm{~m}$ of the creek in relation with the precipitation of amorphous $\mathrm{As}(\mathrm{V})-\mathrm{Fe}(\mathrm{III})$ and $\mathrm{As}(\mathrm{III})-\mathrm{Fe}(\mathrm{III})$ gels and tooeleite (Casiot et al., 2003; Morin et al., 2003). At $1.5 \mathrm{~km}$ from its source,

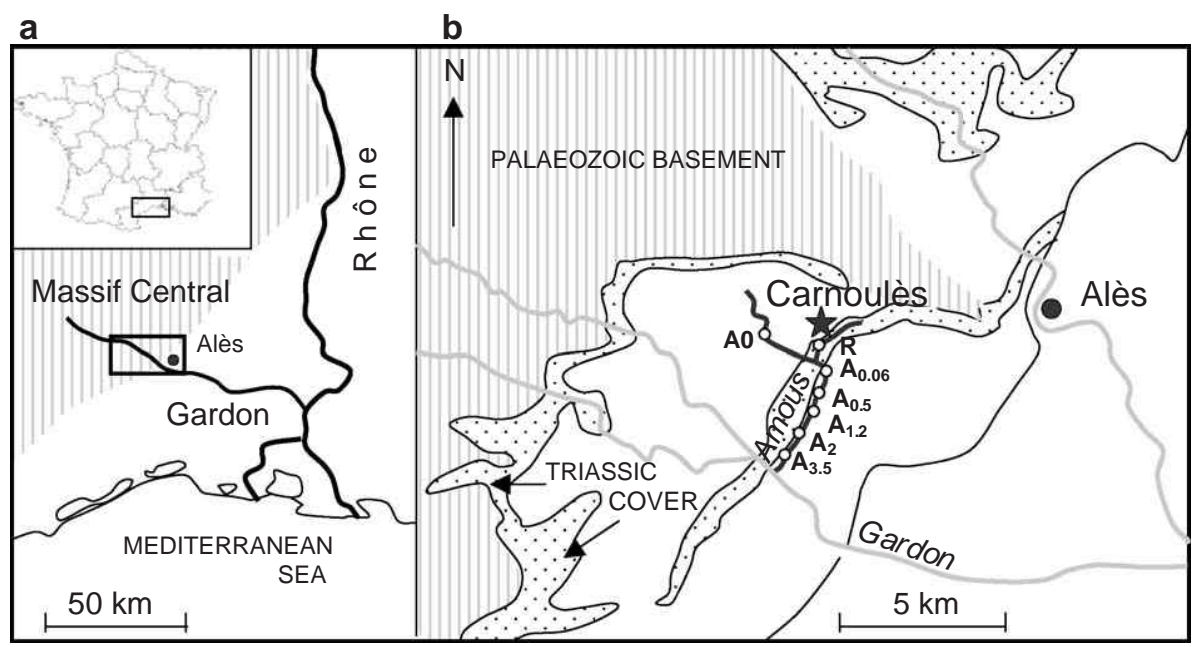

Fig. 1. Site localisation (a) and sampling stations (b). The station in Reigous creek (R) is situated $3 \mathrm{~m}$ upstream from the confluence; in Amous river, stations are situated $1.5 \mathrm{~km}$ upstream from the confluence $\left(\mathrm{A}_{0}\right)$ and $0.06 \mathrm{~km}\left(\mathrm{~A}_{0.06}\right), 0.5 \mathrm{~km}\left(\mathrm{~A}_{0.5}\right), 1.2 \mathrm{~km}\left(\mathrm{~A}_{1.2}\right), 2 \mathrm{~km}\left(\mathrm{~A}_{2}\right)$ and $3.5 \mathrm{~km}$ $\left(\mathrm{A}_{3.5}\right)$ downstream from the confluence. 
the Reigous creek meets the relatively pristine Amous river. After the junction, the water becomes yellowish and the fishes disappear at a few hundred meters.

The mean annual rainfall at the site is $1100 \mathrm{~mm}$, with a seasonal distribution typical of the Mediterranean climate including long drought periods and intense precipitation events especially in spring and autumn. The 21-month period investigated was marked by a dramatic flooding in September 2002 and extreme heatwave during summer 2003. The flow rate of the Reigous creek, measured continuously during the year 2003, varied between 0.2 and $20 \mathrm{l} / \mathrm{s}$, with highest values in spring and winter. For the Amous river, the highest values (150 1/s) are generally reached in autumn while the flow rate averages $100 \mathrm{l} / \mathrm{s}$ in spring and $50 \mathrm{l} / \mathrm{s}$ in summer. Both rivers have a thin $(<30 \mathrm{~cm})$ water layer and are well oxygenated (DO $\geq 5 \mathrm{mg} / \mathrm{l})$.

\section{Materials and methods}

\subsection{Sampling and analyses}

Water samples were collected during 10 surveys carried out over one year from spring 2002 to autumn 2003. The sampling stations are shown in Fig. 1b. The $\mathrm{pH}$ and conductivity were measured in the field with an Ultrameter ${ }^{\mathrm{TM}}$ Model 6P (Myron L Company, Camlab, Cambridge). Water samples were filtered immediately through $0.22 \mu \mathrm{m}$ Millipore membranes fitted on Sartorius polycarbonate filterholders. Samples for major cations $\left(\mathrm{Ca}^{2+}, \mathrm{Na}^{+}, \mathrm{Mg}^{2+}\right)$ determination were acidified to $\mathrm{pH}=1$ with $\mathrm{HNO}_{3}(14.5 \mathrm{M})$ and stored at $4{ }^{\circ} \mathrm{C}$ in polyethylene bottles until analysis. The samples for anions $\left(\mathrm{Cl}^{-}, \mathrm{SO}_{4}^{2-}\right)$ determination and As speciation were frozen to avoid chemical species conversion. Unfiltered samples were used for carbonate determination. Suspended particulate matter (SPM) corresponding to size fraction $>0.22 \mu \mathrm{m}$ was mineralised on a hot plate in concentrated $\mathrm{HNO}_{3}\left(80{ }^{\circ} \mathrm{C}, 24 \mathrm{~h}\right)$. Suspended sediments settled on gravels and cobbles were collected in Reigous creek and Amous river in October 2002 and February, March and May 2003 for solid phase characterization and arsenic speciation.

Analyses of major cations and anions were carried out by capillary electrophoresis (Waters Capillary Ion
Analyzer, Waters, France). $\mathrm{HCO}_{3}^{-}$and $\mathrm{CO}_{3}^{2-}$ were determined by titration with $\mathrm{HCl} 0.05 \mathrm{M}$. Analyses of inorganic $(\mathrm{As}(\mathrm{III})$ and $\mathrm{As}(\mathrm{V}))$ arsenic species were carried out using anion-exchange chromatography (25 $\mathrm{cm} \times 4.1 \mathrm{~mm}$ i.d. Hamilton PRP-X100 column with ProStar gradient solvent delivery system (Varian Analytical Instruments, France) coupled to Hydride Generation (HG) (VGS 200, FISONS, France) with Atomic Fluorescence Spectrometry (AFS) detector (Excalibur, PSAnalytical, GB). The method, described by Bohari et al. (2001), has a detection limit of 0.17 $\mu \mathrm{g} / \mathrm{l}$ for $\mathrm{As}(\mathrm{III})$ and $0.46 \mu \mathrm{g} / \mathrm{l}$ for $\mathrm{As}(\mathrm{V})$ and $\mathrm{a}$ precision better than $5 \%$. Total $\mathrm{Fe}$ (dissolved and colloidal) was determined by Flame or Graphite Furnace Atomic Absorption Spectrometry (Thermo Electron Corporation, France). Tl and Mn concentrations were determined using ICP-MS ("Option S" PQ2+, VG-Elemental, Fisons).

\subsection{Solid samples characterization}

Crystalline phases were identified using X-ray powder diffraction (XRD). XRD data were collected with a PHILIPS PW1710 diffractometer using $\mathrm{Co}-\mathrm{K} \alpha$ radiation operating at $40 \mathrm{kV}, 30 \mathrm{~mA}$ in step scan mode, between 3 and $-90^{\circ} 2 \theta$ with a $0.03^{\circ} 2 \theta$ step and a counting time of 8-20 s per step. Samples were loaded on hollowed aluminum plates.

\subsection{XANES spectroscopy}

Oxidation state of arsenic in field samples was studied using X-ray Absorption Near-Edge Structure (XANES) spectroscopy. Data were recorded at the As $\mathrm{K}$-edge at room temperature in transmission mode on the D44 bending-magnet beamline at the Laboratoire pour l'Utilisation du Rayonnement Electromagnétque (LURE, Orsay, France) or at a temperature of $10 \mathrm{~K}$ on the BM30 beamline at the European Synchrotron for Radiation Facility (ESRF, Grenoble, France). The oxidation state of arsenic was determined in natural samples by linear-least squares fitting of their XANES spectra using a set of experimental XANES spectra of relevant model compounds. Those include cpp5 (FeAs(V) coprecipitate), Shc5 and Sha5 (respectively, As $(V)$ coprecipitated with schwertmannite and sorbed onto schwertmannite), Fh5 (As(V) sorbed onto ferrihydrite), cpp3 (Fe-As(III) coprecipitate), Shc3 
and Sha3 (respectively, As(III) coprecipitated with schwertmannite and sorbed onto schwertmannite) and Fh3 (As(III) sorbed onto ferrihydrite). Absolute accuracy on the $\mathrm{As}(\mathrm{III}) / \sum$ As ratio was $\pm 2 \%$, as determined by fitting of synthetic mixtures of reference compounds (Morin et al., 2003).

\section{Results}

\subsection{Main physico-chemical characteristics}

The main physico-chemical characteristics of the water from Reigous and Amous rivers are presented in Table 1 . The Reigous creek water is characterized by low $\mathrm{pH}(\leq 4.9)$ except during summer 2003 where it reached near-neutral values as a result of increased contribution of unpolluted tributaries at lowest water level. Conductivity is higher than $1100 \mu \mathrm{S} / \mathrm{cm}$, with water chemistry dominated by sulphate $(767 \pm 8 \mathrm{mg} / \mathrm{l})$, $\mathrm{Ca}(220 \pm 72 \mathrm{mg} / \mathrm{l}), \mathrm{Mg}(62 \pm 18 \mathrm{mg} / \mathrm{l})$ and $\mathrm{Fe}(31 \pm 23$ $\mathrm{mg} / \mathrm{l}$ ). Extremely high As concentrations (up to 3.9 $\mathrm{mg} / \mathrm{l}$ ) were recorded in relation with the oxydation of As-rich pyrite within the tailings impoundment (Casiot et al., 2003). Both As and Fe concentrations were drastically lower during summer 2003 while sulphate did not decrease throughout this period, showing increased precipitation of Fe and As in Reigous creek, which might be related to higher $\mathrm{pH}$ values.

The Amous river water is slightly alkaline $(\geq 7.3)$ with a composition dominated by $\mathrm{Ca}(82 \pm 17 \mathrm{mg} / \mathrm{l})$ and hydrogenocarbonate $(285 \pm 7 \mathrm{mg} / \mathrm{l})$. Downstream the confluence with the Reigous creek, the $\mathrm{pH}$ decreases by up to $1.6 \mathrm{pH}$ units at station $\mathrm{A}_{0.06}$ in spite of carbonate buffering and then increases until it reaches $8.0 \pm 0.1$ after station $\mathrm{A}_{1.2}$ (data not shown). The conductivity increases by $24 \pm 6 \%$ on average in relation with increasing $\mathrm{Ca}, \mathrm{Mg}$ and sulphate concentrations. The increase was even higher (2- to 3-fold) during summer 2003. Fe concentrations remained lower than $0.07 \mathrm{mg} / \mathrm{l}$ downstream the confluence, showing rapid precipitation of $\mathrm{Fe}$ as AMD is neutralized.

Mixing ratios ( $\left.\chi_{\text {Reigous }}\right)$ based on the relative contribution that Reigous creek makes to the total mass of individual constituents downstream of its confluence with Amous river have been calculated according to the following equation: $\chi_{\text {Reigous }}=\left(C_{\mathrm{A} 0.06}{ }^{-}\right.$

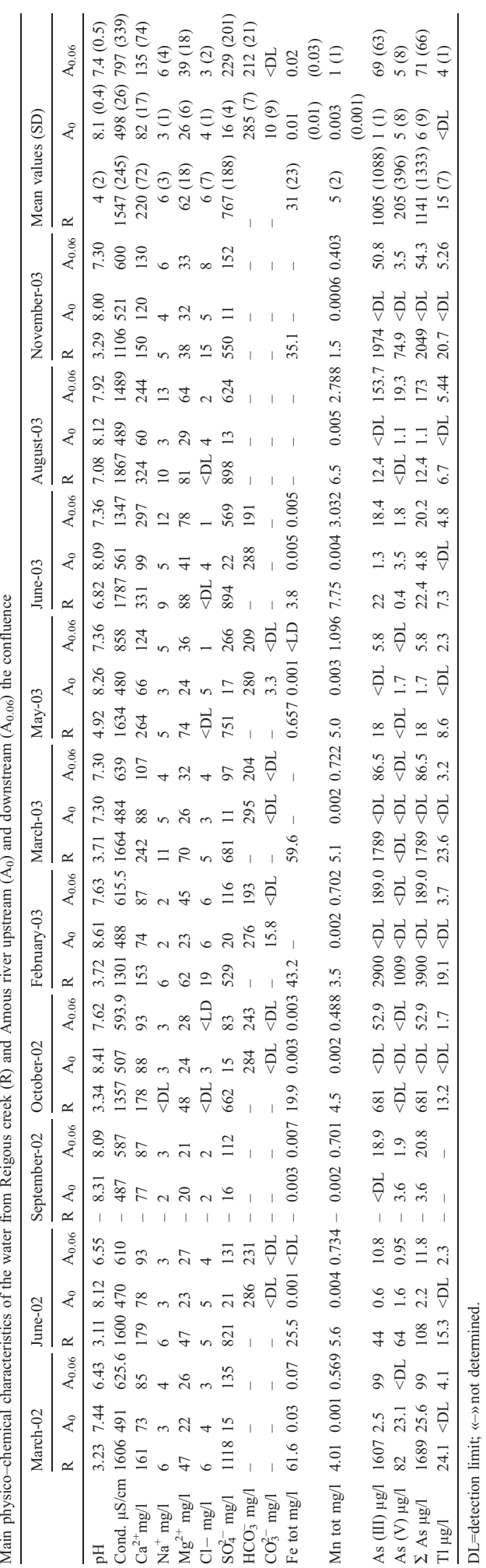




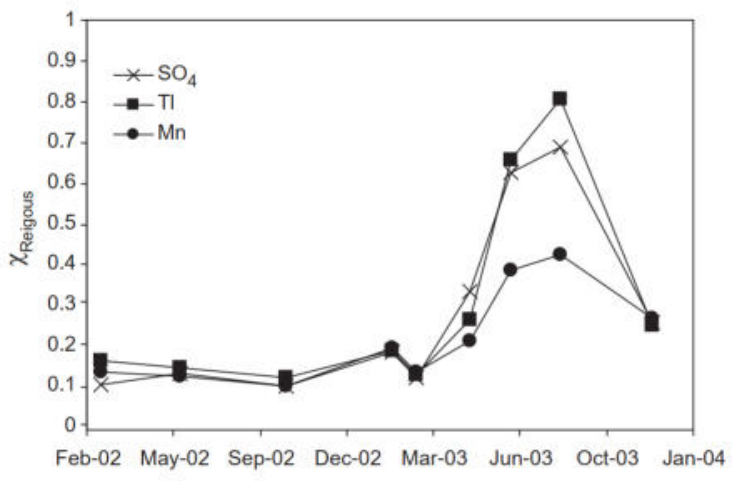

Fig. 2. Evolution of mixing ratios ( $\left.\chi_{\text {Reigous }}\right)$ at the confluence between Reigous and Amous rivers calculated from $\mathrm{SO}_{4}, \mathrm{Tl}$ and $\mathrm{Mn}$ concentrations, according to Gault et al. (2003) : $\chi_{\text {Reigous }}=\left(C_{A 0.06}-\right.$ $\left.\mathrm{C}_{\mathrm{A} 0}\right) /\left(\mathrm{C}_{\mathrm{R}}-\mathrm{C}_{\mathrm{A} 0}\right)$, where $\mathrm{C}_{\mathrm{A} 0}$ and $\mathrm{C}_{\mathrm{A} 0.06}$ are the constituent concentrations in Amous river upstream and downstream the confluence, respectively, and $C_{R}$ is the concentration in Reigous creek.

$\left.C_{\mathrm{A} 0}\right) /\left(C_{\mathrm{R}}-C_{\mathrm{A} 0}\right)$ (Gault et al., 2003), where $C_{\mathrm{A} 0}$ and $C_{\mathrm{A} 0.06}$ are the constituent concentrations in Amous river upstream and downstream the confluence (station $\mathrm{A}_{0.06}$ ), respectively, and $C_{\mathrm{R}}$ is the concentration in Reigous creek. Mixing ratios were similar when calculated from sulphate and $\mathrm{Tl}$ concentrations while Mn gave a lower contribution of Reigous creek in summer 2003 (Fig. 2). Such difference suggests a conservative mixing for $\mathrm{Tl}$ and $\mathrm{SO}_{4}$ while $\mathrm{Mn}$ is partially removed from the aqueous phase at the confluence (Gault et al., 2003). This conservative behaviour of $\mathrm{Tl}$ was confirmed during mixing experiments with various proportions of Reigous and Amous river water (data not shown), which allowed to use this element as a tracer of dilution at the confluence and for downstream sites below the confluence.

According to mixing ratios from Fig. 2, the contribution of the Reigous creek to the Amous river flow ranges between $10 \%$ and $80 \%$, with a maximum in summer 2003, in agreement with extremely high increase in conductivity.

\subsection{Arsenic in the aqueous phase}

In Reigous creek water, the As concentrations are comprised between 12 and $3900 \mu \mathrm{g} / 1$ (Table 1). They decrease by one order of magnitude after mixing with Amous river (station A0.06), except during summer 2003 (especially August) when they are surprisingly higher in Amous river than in Reigous creek (Table
1). The corresponding $\mathrm{As} / \mathrm{Tl}$ ratio varies drastically during the flow from Reigous creek (R) to Amous river $\left(A_{0.06}\right)$ (Fig. 3), implying that dilution is not the only process controlling As concentrations in the mixing zone. As/Tl is generally lower in the mixing zone $\left(\mathrm{A}_{0.06}\right)$ than in Reigous creek, which implies that As is removed from the aqueous phase; however, the reverse is observed during summer 2003 which indicates As release from the suspended particles or sediment to the aqueous phase (Fig. 3). Little variation of As/Tl ratio occurs further downstream in the cooler months (March 2002 and February and March 2003), showing little exchange between aqueous and solid phases. Conversely, the $\mathrm{As} / \mathrm{Tl}$ ratio still increases downstream the mixing zone during the warm period, implying desorption from the sediment along the flowpath. However, there was no correlation between the evolution of $\mathrm{As} / \mathrm{Tl}$ ratio dowstream station $\mathrm{A}_{0.06}$ and the slight $\mathrm{pH}$ increase measured between $\mathrm{A}_{0.06}$ and $\mathrm{A}_{1.2}$.

The dominant As species in Reigous creek is generally As(III) (>95\%) although As(V) may be present occasionally $(60 \%$ of total As in June 2002 and $26 \%$ in February 2003) (Table 1). When As(V) is present in significant proportion in Reigous creek $(\mathrm{As}(\mathrm{V}) / \mathrm{As}(\mathrm{III})>0.1)$, it is efficiently removed from the aqueous phase in the mixing zone compared to As(III) according to the drastic decrease of the $\mathrm{As}(\mathrm{V}) / \mathrm{As}(\mathrm{III})$ ratio between stations $\mathrm{R}$ (Reigous) and $\mathrm{A}_{0.06}$ (Amous) (Fig. 4a). As a consequence, As(III) is the dominant species $(\geq 90 \%)$ at station $A_{0.06}$. Downstream station $\mathrm{A}_{0.06}$, there is a general increase of $\mathrm{As}(\mathrm{V}) / \mathrm{As}(\mathrm{III})$ ratio

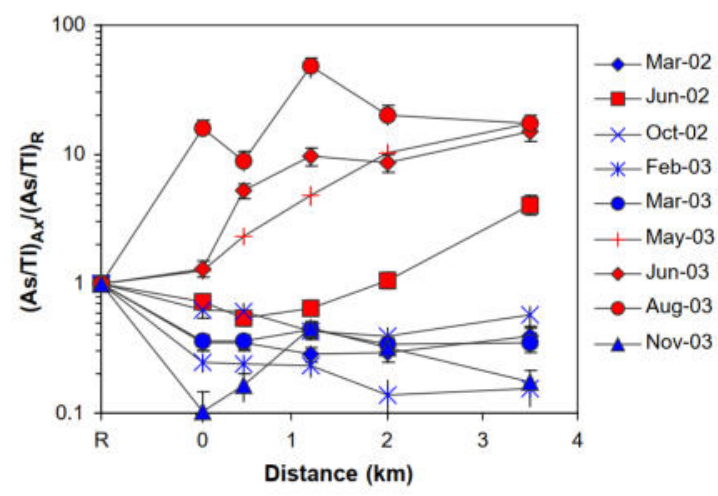

Fig. 3. Variation of the aqueous $\mathrm{As} / \mathrm{Tl}$ ratio at each sampling site in Amous river downstream the confluence $\left(\mathrm{As} / \mathrm{Tl}_{\mathrm{Ax}}\right)$ normalized to the ratio in Reigous creek (As/ $\left./ l_{R}\right)$. 

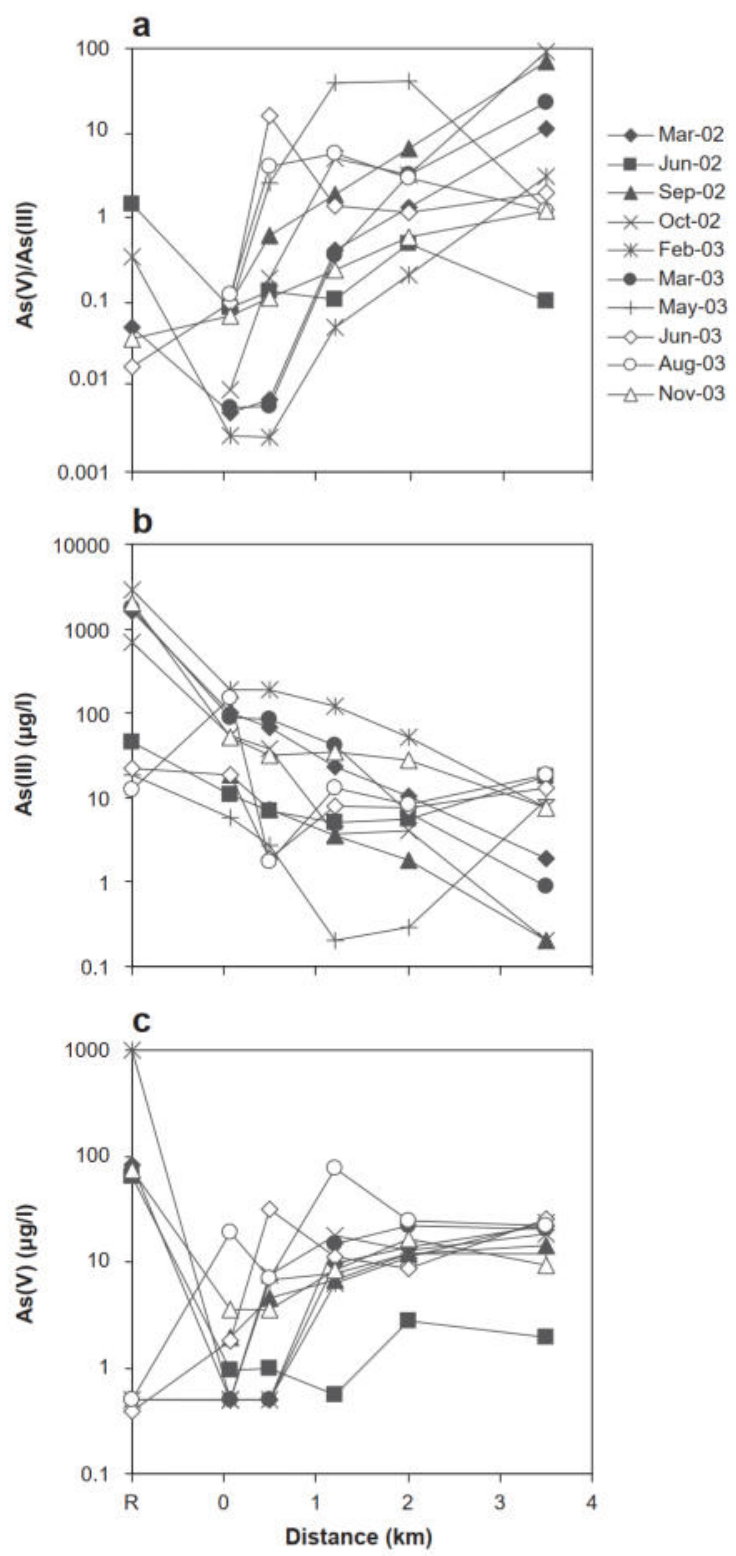

Fig. 4. Evolution of aqueous $\mathrm{As}(\mathrm{V}) / \mathrm{As}(\mathrm{III})$ ratios (a), $\mathrm{As}$ (III) (b) and $\mathrm{As}(\mathrm{V})$ concentrations (c) for sampling stations in Reigous creek (R) and in Amous river downstream the confluence.

away from the confluence (Fig. 4a) in relation with a decrease of As(III) concentration (Fig. 4b) and a concomitant increase of $\mathrm{As}(\mathrm{V})$ (Fig. 4c) which becomes predominant after a few kilometers. Nevertheless, a slight As(III) increase was recorded downstream station $\mathrm{A}_{2}$ during the warm period (Fig. 4b).

\subsection{Arsenic in the particulate phase}

SPM from Reigous creek and Amous river both contain $\mathrm{Fe}$ as the main component (up to $56 \mathrm{wt} . \%$ ) (Table 2); however, the phases progressively transform from schwertmannite (Sch) in the Reigous creek to ferrihydrite $(\mathrm{Fh})$ in the Amous River (from the top to the bottom of Fig. 5), corresponding to the $\mathrm{pH}$ stability field of these minerals $(\mathrm{pH} 3-4$ for schwertmannite and $>5$ for ferrihydrite) derived from AMD (Yu et al., 1999). Seasonal fluctuations of the As content of SPM in Amous river follow those of Reigous creek (Table 2); highest values are recorded during the cold period and lowest values during the warm period, in relation with the variations of As concentrations in the aqueous phase (Table 1). However, the corresponding $\mathrm{As} / \mathrm{Fe}$ molar ratios in SPM from Amous river reached higher values in summer 2003 (up to 0.9 at station $\mathrm{A}_{3.5}$, data not shown) compared to other periods $(\mathrm{As} / \mathrm{Fe}=0.01-0.05)$, in relation with a lower Fe content (Table 2). XANES data indicates that $\mathrm{As}(\mathrm{V})$ is predominant in freshly settled sediment, both in Reigous creek (As(V) $\geq 51 \%$ ) and in Amous river $(\mathrm{As}(\mathrm{V}) \geq 69 \%)$, unlike species distribution in the aqueous phase.

\section{Discussion}

Reigous acid creek supplies high amounts of As(III) to the Amous river. However, this supply varies seasonally; the lowest concentrations were measured during the warm season and the highest during the cold period whereas sulphate, which is a tracer of As-rich pyrite dissolution, is relatively stable. This suggests that natural attenuation processes lower the concentrations of $\mathrm{As}(\mathrm{III})$ in the warm period. The formation of $\mathrm{As}(\mathrm{V})$-bearing compounds through bacteria-catalysed As(III) oxidation is promoted in the warm period in the upper course of Reigous creek (Casiot et al., 2003; Morin et al., 2003). Furthermore, increased $\mathrm{pH}$ values as a result of dilution by unpolluted tributaries also contribute to increase As and $\mathrm{Fe}$ precipitation at lowest water level. However, the solid phase formed upstream from the confluence, schwertmannite, differs from $\mathrm{As}(\mathrm{V})-\mathrm{Fe}(\mathrm{III})$ oxyhydroxides formed in the upper part of Reigous creek (Morin et al., 2003). Besides the higher $\mathrm{pH}$ in the 
Table 2

As and Fe content in SPM of Reigous creek and Amous river and the corresponding As/Fe molar ratio and As speciation

\begin{tabular}{|c|c|c|c|c|c|c|c|c|}
\hline & \multicolumn{4}{|l|}{ Reigous } & \multicolumn{4}{|l|}{ Amous } \\
\hline & $\begin{array}{l}\text { As } \\
(\mathrm{mg} / \mathrm{g})\end{array}$ & $\begin{array}{l}\mathrm{Fe} \\
(\mathrm{mg} / \mathrm{g})\end{array}$ & $\begin{array}{l}\mathrm{As} / \mathrm{Fe} \\
(\mathrm{mol} / \mathrm{mol})\end{array}$ & $\begin{array}{l}\operatorname{As}(\mathrm{III}) / \text { As total } \\
(\%)^{\dagger}\end{array}$ & $\begin{array}{l}\mathrm{As}^{\#} \\
(\mathrm{mg} / \mathrm{g})\end{array}$ & $\begin{array}{l}\mathrm{Fe}^{\#} \\
(\mathrm{mg} / \mathrm{g})\end{array}$ & $\begin{array}{l}\mathrm{As} / \mathrm{Fe}^{\#} \\
(\mathrm{~mol} / \mathrm{mol})\end{array}$ & $\begin{array}{l}\mathrm{As}(\mathrm{III}) / \text { As total } \\
(\%)^{\dagger}\end{array}$ \\
\hline Mar-02 & 149 & 391 & 0.28 & & $12 \pm 2$ & $270 \pm 26$ & $0.034 \pm 0.003$ & \\
\hline Jun-02 & & & & & $1 \pm 1$ & $82 \pm 95$ & $0.012 \pm 0.004$ & \\
\hline Sep-02 & & & & & $4 \pm 1$ & $127 \pm 25$ & $0.023 \pm 0.002$ & \\
\hline Oct-02 & 31 & 565 & 0.04 & 19 & $6 \pm 3$ & $221 \pm 118$ & $0.022 \pm 0.004$ & $8^{*}$ \\
\hline Feb-03 & 56 & 298 & 0.14 & 31 & $19 \pm 6$ & $295 \pm 144$ & $0.05 \pm 0.02$ & $31 * *$ \\
\hline Mar-03 & 28 & 561 & 0.04 & 49 & $15 \pm 4$ & $237 \pm 84$ & $0.05 \pm 0.01$ & $24 *, 29 * *$ \\
\hline May-03 & 1 & 170 & 0.004 & 25 & $3 \pm 1$ & $69 \pm 70$ & $0.1 \pm 0.1$ & $25 * *$ \\
\hline Jun-03 & 2 & 308 & 0.005 & & $3 \pm 1$ & $55 \pm 89$ & $0.3 \pm 0.4$ & \\
\hline Aug-03 & 5 & 230 & 0.02 & & $4 \pm 2$ & $44 \pm 16$ & $0.07 \pm 0.05$ & \\
\hline Nov-03 & 46 & 219 & 0.16 & & $10 \pm 1$ & $217 \pm 70$ & $0.04 \pm 0.01$ & \\
\hline
\end{tabular}

* From sample collected at station $\mathrm{A}_{0.06}$.

** From sample collected at station $\mathrm{A}_{1.2}$.

$\dagger$ The oxidation state of As in freshly settled sediments is given by the percentage of As(III) in comparison with total As. The remaining part of arsenic is $\mathrm{As}(\mathrm{V})$.

\# Mean and $\mathrm{SD}$ values calculated from samples $\mathrm{A}_{0.06}, \mathrm{~A}_{0.5}, \mathrm{~A}_{1.2}, \mathrm{~A}_{2}$ and $\mathrm{A}_{3.5}$.

lower course of the creek, the lower $\mathrm{As} / \mathrm{Fe}$ ratios in the solid (0.004-0.14) could make the formation of schwertmannite possible whereas it is degraded at As/ Fe ratio $>0.15$ (Carlson et al., 2002). This phase

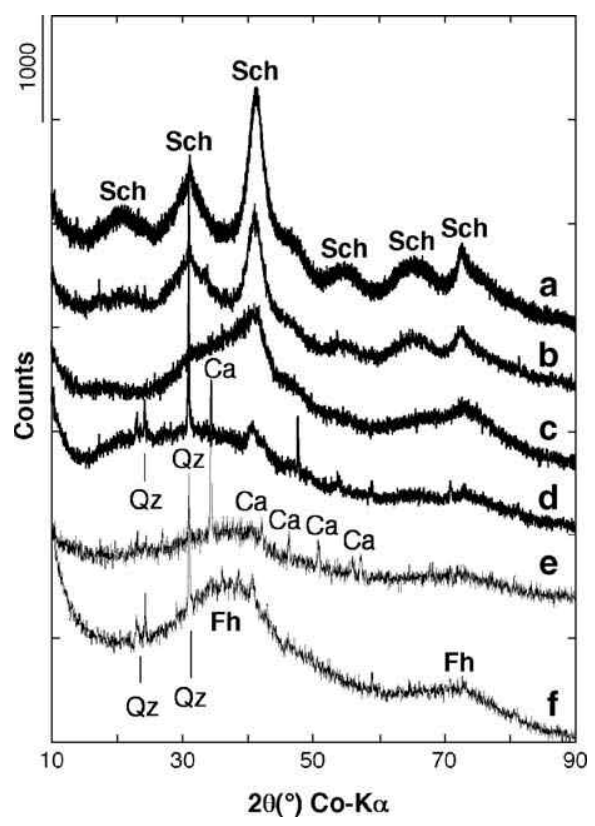

Fig. 5. XRD patterns of freshly settled sediment from Reigous Creek (a, b), Amous River $3 \mathrm{~m}$ after the confluence (c, d) and 1200 $\mathrm{m}$ after the confluence (station $\mathrm{A}_{1.2}$ ) (e, f) in May 2003 (a, c, e) and February 2003 (b, d, f). (e) was multiplied by 1.5. Sch: schwertmannite, Fh: ferrihydrite, Qz: quartz, Ca: calcite. appears to trap both $\mathrm{As}(\mathrm{III})(20-50 \%)$ and $\mathrm{As}(\mathrm{V})$. This capability had been demonstrated for $\mathrm{As}(\mathrm{V})$ in both natural and synthetic schwertmannite (Carlson et al., 2002) while As(III) adsorption on this mineral occurred as a result of bacterial-mediated Fe precipitation (Duquesne et al., 2003). Despite these natural attenuation processes, $\mathrm{As}(\mathrm{III})$ is still present at high concentrations in the aqueous phase of Reigous creek upstream from the confluence with Amous river.

In the mixing zone, $\mathrm{Fe}$ is completely removed from the aqueous phase due to rapid oxidation of $\mathrm{Fe}(\mathrm{II})$ at near-neutral $\mathrm{pH}$. This results in the formation of ferrihydrite, which is a common mineral in mineimpacted rivers (Carlson et al., 2002). With the exception of summer 2003, arsenic concentrations are lowered by one order of magnitude in the mixing zone as a result of 5- to 10-fold dilution with Amous river and trapping of $\mathrm{As}(\mathrm{III})$ and $\mathrm{As}(\mathrm{V})$ on ferrihydrite. Indeed, ferrihydrite has a strong affinity for both $\mathrm{As}(\mathrm{III})$ and $\mathrm{As}(\mathrm{V})$ at neutral $\mathrm{pH}$ (Raven et al., 1998; Pierce and Moore, 1980) which results in relatively high As/Fe ratios (0.02-0.05) in SPM of Amous river. However, $\mathrm{As}(\mathrm{V})$ was predominant in freshly settled sediment ( $\geq 69 \%$ of total As) compared to the corresponding aqueous phase $(\mathrm{As}(\mathrm{V})<11 \%)$. This implies partial As(III) oxidation, either in the aqueous phase at the mixing zone or during ageing of the sediment after settling. This As(III) oxidation could be due to Fenton reaction which is known to occur in 
oxygenated neutral waters containing Fe(II, III) (Hug and Leupin, 2003).

Downstream the mixing zone, the transport of arsenic is affected seasonally. During the cooler months (March 2002 and February and March 2003), arsenic is transported nearly conservatively along Amous river flowpath according to relatively stable As/Tl ratios. Furthermore, there is an increase of $\mathrm{As}(\mathrm{V}) / \mathrm{As}(\mathrm{III})$ ratio, which suggests $\mathrm{As}$ (III) oxidation in solution. This process is generally slow in natural waters (Cherry et al., 1979) and it is unlikely to occur through light-induced As(III) oxidation (Hug et al., 2001) since this process requires the presence of dissolved $\mathrm{Fe}$, which is scarce in Amous river downstream station $\mathrm{A}_{0.06}$. However, As(III) oxidation can be enhanced in AMD environments through Mnoxides surface-catalyzed reactions (Oscarson et al., 1980) or bacterial catalysis (Oremland and Stolz, 2003). Thus, there is an increase of aqueous $\mathrm{As}(\mathrm{V})$ concentration along the flowpath. Therefore, it appears that $\mathrm{As}(\mathrm{V})$ from $\mathrm{AMD}$ may be transported over long distances, as demonstrated for arsenic from geothermal waters (Nimick et al., 1998). In contrast, during the warm season, there is an increase of As/Tl ratio away from the confluence together with increasing As(III) concentrations downstream station $\mathrm{A}_{2}$. This suggests desorption of As(III) from the solid phase. This phenomenon is enhanced in extremely dry conditions of summer 2003, which might be attributed to the equilibrium of As concentrations between river water and As-rich solids. Increased As leaching from the sediment was observed at low flow conditions in mine-impacted river (Mok and Wai, 1990) and attributed to longer sediment-water contact time. Furthermore, As(III) was the almost exclusive species released under aerobic conditions in laboratory experiments (Mok and Wai, 1990). Such As(III) release has been attributed to the reduction of Fe-oxyhydroxides in the hyporheic zone of a contaminated stream and the transfer of sediment-bound As to the aqueous phase as As(III), which does not immediately reoxidize (Nagorski and Moore, 1999). Although the extreme character of summer 2003 may overestimate the general capability of As to be transferred from sediment to river water, it points out that river sediments are not an efficient trap for As; on the contrary they may act as a major source of As to the aquatic system during summer months.

\section{Acknowledgements}

This study was funded by the CNRS INSU-SdU (Programme ATIP Jeunes Chercheurs) and the CNRSINSU under contract Acide 3 (Programme Geomex).

\section{References}

Bohari Y, Astruc A, Astruc M, Cloud J. Improvements of hydride generation for the speciation of arsenic in natural freshwater samples by HPLC-HG-AFS. J Anal At Spectrom 2001;16: $774-8$.

Carlson L, Bigham JM, Schwertmann U, Kyek A, Wagner F. Scavenging of As from acid mine drainage by schwertmannite and ferrihydrite: a comparison with synthetic analogues. Environ Sci Technol 2002;36:1712-9.

Casiot C, Morin G, Juillot F, Bruneel O, Personné JC, Leblanc M, et al. Bacterial immobilization and oxidation of arsenic in acid mine drainage (Carnoulès creek, France). Water Res 2003;37: 2929-36.

Cherry JA, Shaikh AU, Tallman DE, Nicholson RV. Arsenic species as an indicator of redox conditions in groundwater. J Hydrol 1979;43:373-92.

Duquesne K, Lebrun S, Casiot C, Bruneel O, Personné JC, Leblanc $\mathrm{M}$, et al. Immobilization of arsenite and ferric iron by Acidithiobacillus ferrooxidans and its relevance to acid mine drainage. Appl Environ Microbiol 2003;69(10):6165-73.

Fuller CC, Davis JA. Influence of coupling of sorption and photosynthetic processes on trace element cycles in natural waters. Nature 1989;340:52-4.

Gault AG, Polya DA, Lythgoe PR, Farquhar ML, Charnock JM, Wogelius RA. Arsenic speciation in surface waters and sediments in a contaminated waterway: an IC-ICP-MS and XAS based study. Appl Geochem 2003;18:1387-97.

Hug SJ, Leupin O. Iron-catalyzed oxidation of arsenic(III) by oxygen and by hydrogen peroxide: $\mathrm{pH}$-dependent formation of oxidants in the fenton reaction. Environ Sci Technol 2003; 37(12):2734-42.

Hug SJ, Canonica L, Wegelin M, Gechter D, von Gunten U. Solar oxidation and removal of arsenic at circumneutral $\mathrm{pH}$ in iron containing waters. Environ Sci Technol 2001;35(10): 2114-21.

Kimbal BA, Callender E, Axtmann EV. Effects of colloids on metal transport in a river receiving acid mine drainage, upper Arkansas River, Colorado, USA. Appl Geochem 1995;10(3): $285-306$.

Leblanc M, Achard B, Ben Othman D, Luck JM. Accumulation of arsenic from acidic mine waters by ferruginous bacterial accretions (stromatolites). Appl Geochem 1996;11:541-54.

Mok WM, Wai CM. Distribution and mobilization of arsenic and antimony species in the Coeur d'Alène river, Idaho. Environ Sci Technol 1990;24:102-8.

Morin G, Juillot F, Casiot C, Personné JC, Elbaz-Poulichet F, Leblanc $\mathrm{M}$, et al. Bacterial immobilization and oxidation of arsenic in acid mine drainage (Carnoulès creek, France) XANES 
and XRD evidence of As(V)-or As(III)-Fe(III) gels and tooeleite. Environ Sci Technol 2003;37:1705-12.

Nagorski SA, Moore JN. Arsenic mobilization in the hyporheic zone of a contaminated stream. Water Resour Res 1999; 35(11):3441-50.

Nimick DA, Moore JN, Dalby CE, Savka MW. The fate of geothermal arsenic in the Madison and Missouri rivers, Montana and Wyoming. Water Resour Res 1998;34(11):3051-67.

Oremland RS, Stolz JF. The ecology of arsenic. Science 2003; 300:939-44.

Oscarson DW, Huang PM, Liaw WK. The oxidation of arsenite by aquatic sediments. J Environ Qual 1980;9(4):700-3.

Pierce ML, Moore CB. Adsorption of arsenite on amorphous iron hydroxide from dilute aqueous solution. Environ Sci Technol 1980;14(2):214-6.
Raven KP, Jain A, Loeppert RH. Arsenite and arsenate adsorption on ferrihydrite: kinetics, equilibrium, and adsorption envelopes. Environ Sci Technol 1998;32:344-9.

Roussel C, Bril H, Fernandez A. Evolution of sulphides-rich mine tailings and immobilization of As and Fe. C R Acad Sci 1999; 329:787-94.

Williams M. Arsenic in mine waters : an international study. Environ Geol 2001;40(3):267-78.

Yu JY, Heo B, Choi IK, Cho JP, Chang HW. Apparent solubilities of schwertmannite and ferrihydrite in natural streamwaters polluted by mine drainage. Geochim Cosmochim Acta 1999;63(19-20): 3407-16. 